\title{
PENGARUH IKLIM ORGANISASI TERHADAP KINERJA PEGAWAI PADA FAKULTAS ILMU SOSIAL DAN ILMU POLITIK UNIVERSITAS HALUOLEO
}

Oleh:

\author{
Riston G. Ahmad ${ }^{1}$ \\ ${ }^{1}$ Universitas Muhammadiyah Kendari \\ griston9@gmail.com
}

\begin{abstract}
Due to the problem on how does organization climate influence employee performance faculty of social and politic Haluoleo University, this research aims to analyze wheter organization climate influence employee performance or not by proof the hypotheses based on empirical data from faculty of social and politic Haluoleo University, and to analyze significant level of organization climate to employee performance.

This research tests several organization climate variabel which includes individual autonomy dimension, sanction orientation, visibility of structure and motivation, and also employee performance variables that consist of productivity, served quality, respont, responsibility, aquntability

In this research, we use descriptive, verification, and correlation analysis to analyze causality of influences by using survey methods to measure and analyze how big the influences of organization climate to employee performance in faculty of social and politic Haluoleo University . By quantitative approach and statistical test.

Data had been collected by using questionnaire as primary instrument, interview, documentation, and literacy study as a secondary data. Then, those data proceed by using determination and product correlation analysis.

The result of this research showed that organization climate has a strong, significant, an positive influence to employee performance in faculty of social and politic Haluoleo University. Organization climate become dominant factor which influences the employee. This research also has proven that employee performance will raise when its organization climate getting better.
\end{abstract}

Keywords : Organization, Employee Performance 


\section{PENDAHULUAN}

Organisasi bisa berdiri diawali adanya beberapa tujuan tertentu yang hanya dapat dicapai melalui tindakan yang harus dilakukan dengan persetujuan bersama. Jadi apabila tujuan itu membawa kebaikan bagi anggota maupun masyarakat, namun ciri organisasi itu sama. Sebagaimana dikemukakan James I. Gibson (1989:3) perilakunya terarah pada tujuan (directed behavior). Artinya organisasi itu mengejar tujuan dan sasaran yang dapat dicapai secara lebih efisien dan lebih efektif dengan tindakan yang dilakukan secara bersama-sama.

Terwujudnya suatu organisasi yang baik, bagaimanapun juga akan ditentukan beberapa hal antara lain tergantung pada hal-hal yang mendasar, yakni nilai-nilai dan norma-norma organisasional yang dianut dan termanifestasi pada setiap instansi/lembaga pemerintah. Nilai-nilai dan norma-norma tersebut secara langsung maupun tak langsung, secara sadar maupun tak sadar, memberi pedoman dan mengarahkan serta mengkondisikan terbentuknya perilaku dan budaya kerja pegawai yang berorientasi pada terciptanya kinerja yang optimal. Nilai-nilai dan budaya organisasional ketika memanifestasikan suatu kondisi atau suasana kerja yang dirasakan oleh anggota organisasi dikenal sebagai iklim organisasi.

Pembentukan dan pemeliharaan iklim organisasi yang kondusif bagi pegawai untuk berkinerja optimal tidak terlepas dari upaya-upaya peningkatan aktivitas kerja para pegawai. Dalam berbagai dimensi psikologis dan sosial ekonomi, para pegawai relatif berbeda-beda antara yang satu dengan yang lainnya. Perbedaan tersebut dapat menyebabkan adanya kondisi yang relatif berbeda pula jenis dan tingkatan kebutuhannya, baik kebutuhan yang dirasakan (felt needs) maupun kebutuhan ril (real needs), maupun preferensinya terhadap tugas pekerjaan organisasional. Jenis dan tingkat kebutuhan yang berbeda, tentunya, memanifestasikan motivasi kerja yang relatif berbeda, hal itu akan berpengaruh pada kinerja pegawai pada instansinya.

Upaya mewujudkan kinerja pegawai yang optimal pada sebuah organisasi melalui penciptaan dan pemeliharaan suatu iklim organisasi yang kondusif di satu sisi, serta peningkatan dan pemeliharaan motivasi kerja para pegawainya. Di sisi lain, sangat tergantung pada gaya kepemimpinan dari para pemimpin di dalam organisasi yang bersangkutan. Fakultas Ilmu Sosial dan Ilmu Politik merupakan salah satu unit organisasi dalam lingkungan Universitas Haluoleo dengan tugas utama mengemban tridharma Perguruan Tinggi, yang meliputi : Pendidikan dan Pengajaran, Penelitian dan Pengabdian pada masyarakat, dengan jumlah staf dan dosen sebagai pegawai terdiri atas : PNS / staf administrasi 23 orang, Dosen 94 orang dan Pegawai Harian Tetap (PHT) 30 orang, sehingga jumlah keseluruhannya adalah 147 orang.

Dalam melaksanakan tugas masing-masing, baik pegawai tetap, pegawai harian maupun dosen sebagai tenaga edukatif telah terjadi hubungan dan interaksi yang baik. Hubungan yang baik ini tentu saja di dukung dengan lingkungan organisasi yang baik yang memungkinkan setiap orang merasa nyaman untuk melakukan aktivitasnya masing-masing sesuai dengan tugas dan kedudukannya dalam organisasi.

Iklim organisasi yang baik sangat mendukung kinerja staf dalam organisasi, dimana setiap staf dapat melaksanakan tugas dan kewajibannya dengan secara optimal. Namun hasil pengamatan awal realita yang terjadi di lingkungan Fakultas Ilmu Sosial dan Ilmu Politik kondisi iklim organisasi saat ini belum menunjukkan adanya korelasi yang signifikan, dimana lingkungan organisasi yang kurang kondusif dan kinerja pegawai masih relatif rendah atau belum optimal. Rendahnya kinerja tersebut, kurang memberi motivasi terhadap pegawai dalam melaksanakan tugas dan pekerjaan sebagai abdi negara. Hal ini seperti yang dikemukakan oleh Jatman (2002 : 66) bahwa pegawai mempunyai semangat yang lemah dalam pengabdian pada kepentingan Publik

Faktor lain yang turut mempengaruhi iklim organisasi yaitu mengenai tingkat disiplin pegawai terutama menyangkut kehadiran pegawai dalam melaksanakan tugasnya. Hal tersebut dapat dilihat pada tingkat kemangkiran atau absensi pegawai Fakultas Ilmu Sosial dan Ilmu Politik Universitas Haluoleo Bulan Januari s/d September 2010 yaitu jumlah pegawai yang tidak hadir 42 orang (8,81 \%), yang sakit 26 orang $(5,45 \%)$, yang izin 22 orang $(4,61 \%)$, yang cuti 6 orang $(1,26 \%)$ dan yang dinas luar berjumlah 18 orang $(3,77)$. Hal ini 
menunjukan tingkat kemangkiran pegawai bila dirata-ratakan mencapai $23,90 \%$ dari jumlah pegawai sebanyak 53 orang. Dari data tersebut dapat ditarik kesimpulan bahwa Pada Fakultas Ilmu Sosial dan Ilmu Politik Universitas Haluoleo terdapat sebanyak 13 orang pegawai atau 23,90 \% rata-rata setiap bulan meninggal tugas dan tanggung jawabnya atau tidak bersungguh-sungguh dalam melaksanakan fungsinya sebagai pelayan publik. Berkaitan dengan tingkat kemangkiran pegawai tersebut menurut asumsi awal penulis bahwa pada Fakultas Ilmu Sosial dan Ilmu Politik Universitas Haluoleo memiliki Iklim organisasi yang kurang kondusif sehingga mengakibatkan masih lemahnya kinerja dan rendahnya produktivitas pegawai yang berimplikasi pada tidak terwujudnya pelayanan masyarakat yang berkualitas.

Ketidakdisiplinan pegawai yang sering terjadi dan mudah diamati biasanya tercermin dari tingginya tingkat absensi, seringnya pegawai datang terlambat pulang lebih cepat dari waktu kerja yang telah ditetapkan, sering terjadi pelanggaran-pelanggaran terhadap aturan yang ada (bersenda gurau pada waktu bekerja, bekerja tidak sesuai dengan tahap-tahap yang ada dan sebagainya.

Kedisiplinan suatu organisasi dikatakan baik, jika sebagian besar pegawai mentaati peraturan-peraturan yang ada. Apabila ketidakdisiplinan terus terjadi maka akan mengganggu aktivitas kerja pegawai sehingga menyebabkan produktivitas organisasi tidak berjalan dengan semestinya. Pada sisi lain, terdapat pula realita/fenomena alasan bahwa pegawai Fakultas Ilmu Sosial dan Ilmu Politik sering berbenturan dengan sikap pimpinan yang tidak terbuka dan terkesan arogan sehingga tugas yang diemban seringkali dilaksanakan secara tidak nyaman. Masalah utama adalah adanya kebijakan pimpinan yang belum dan bahkan tidak berpihak kepada kepentingan pegawai, misalnya menyangkut promosi jabatan yang tidak sesuai dengan ketentuan / aturan kepegawaian, kesejahteraan pegawai yang belum mendapatkan perhatian secara. sungguh - sungguh dari pimpinan atau top manager. Kemudian masalah lain seperti keharusan pegawai bawahan mentaati perintah atasan, sistem yang birokratis dan kurangnya motivasi pegawai menjadi hal yang tidak dapat diabaikan dalam melahirkan kenyataan perilaku pegawai.

Fakultas Ilmu Sosial dan Ilmu Politik sebagai pusat pelayanan seharusnya dapat membentuk perilaku kinerja pegawai yang baik sehingga dapat meningkatkan pelayanan kepada publik dan dapat mengembangkan kemampuan pegawai dengan memperhatikan iklim organisasi yang dirasakannya sehingga dapat bekerja dengan nyaman. Oleh karenanya iklim organisasi selama ini perlu dianalisis.

Merujuk pada eksplanasi di atas, maka penulis tertarik untuk mengkaji "Pengaruh Iklim Organisasi terhadap Kinerja Pegawai Pada Fakultas ilmu Sosial dan Ilmu Politik Universitas Haluoleo"

\section{KAJIAN TEORI}

\section{Konsep Iklim Organisasi}

Efektivitas kepemimpinan seseorang tergantung pada kemampuannya menyesuaikan gaya kepemimpinannya dengan beragam dinamika situasi yang ada pada organisasinya. Hal ini akan "ditunjukkan bahwa situasi organisasi dimaksud tidak lain adalah iklim organisasi.

Konsep iklim organisasi, didalam literatur-literatur, didefinisikan secara (relatif) berbeda. Terguiri dalam Arni Muhammad (2002 : 82) mendefinisikannya sebagai kualitas yang relatif abadi dari lingkungan internal organisasi yang dialami oleh anggota-anggotanya, memenuhi tingkah laku mereka seperti yang diuraikan dalam istilah-istilah nilai-nilai suatu set karakteristik tertentu dari lingkungan.

Defenisi lain tentang iklim organisasi dikemukakan oleh Payne dan Pugh, seperti dikutip pula oleh Muhammad (2002 : 82) bahwa iklim organisasi sebagai suatu konsep yang merefleksikan isi dan kekuatan dari nilai-nilai umum, norma, sikap, tingkah laku dan perasaan anggota terhadap suatu sistem sosial.

Menurut Wexley dan Yuk (1988: 13), organisasi dapat didefinisikan sebagai hubungan-hubungan yang terpolakan di antara orang-orang berurusan dengan aktivitas-aktivitas, ketergantungan yang di arahkan pada 
suatu tujuan tertentu. Sedangkan Sutarsono (1984:36), setelah menelaah sejumlah banyak definisi yang ada tentang organisasi, merumuskan bahwa organisasi adalah sistem saling pengaruhi antara orang dalam kelompok yang bekerja sama untuk mencapai tujuan tertentu.

Kedua definisi organisasi yang dikutip di atas bersubstansi sama, yaitu adanya orang-orang, mereka bekerja sama secara terpola atau terstruktur, mempunyai tujuan bersama yang tertentu. Kedua definisi tersebut mencakup bukan saja organisasi formal tetapi juga organgisasi sosial.

Asumsi dasar dari teori iklim organisasi adalah bahwa persepsi dan perilaku individu masing-masing anggota organisasi akan dipengaruhi bagaimana persepsi dan perilaku anggota lain dalam system organisasi tersebut. Ketika pihak manajemen memandang bahwa kualitas merupakan suatu hal yang mesti dilakukan, persepsi dan perilaku anggota organisasi akan didorong oleh kualitas dalam aktivitas, kerja.

Menurut Gibson (1989:5) bahwa iklim organisasi yang baik sangat mendukung kinerja staf dalam organisasi, dimana setiap staf dapat melaksanakan tugas dan kewajibannya dengan secara optimal.

Semua organisasi tentu memiliki strategi dalam memanajemen SDM. Iklim organisasi yang terbuka memacu aparat untuk mengutarakan kepentingan dan ketidakpuasan tanpa adanya rasa takut akan tindakan balasan dan perhatian. Iklim keterbukaan, hanya akan tercipta jika semua anggota memiliki tingkat keyakinan yang tinggi dan mempercayai keadilan tindakan. Iklim organisasi penting untuk diciptakan karena merupakan persepsi seseorang tentang apa yang diberikan oleh organisasi. Iklim organisasi ditentukan oleh seberapa baik anggota diarahkan, dibangun dan dihargai oleh organisasi.

Setiap pembahasan konsep iklim organisasi, pada dasarnya membahas mengenai sifat-sifat atau ciri-ciri yang terdapat dalam lingkungan kerja, yang timbul karena kegiatan organisasi yang dilakukan secara sadar atau tidak dan dianggap mempengaruhi perilaku para aparatur.

Menurut Steers (1985 : 101), iklim organisasi merupakan lingkungan internal yang mewakili faktor-faktor dalam organisasi yang menciptakan kultur dan lingkungan sosial di mana aktivitas - aktivitas pencapaian tujuan berlangsung. Lebih lanjut Steers (1985 : 167), mengemukakan bahwa ada empat strategi pokok untuk mengembangkan lingkungan kerja yang mengarah pada tujuan, yaitu : (l) pemilihan dan penempatan pekerja; (2) pendidikan dan pengembangan; (3) desain/rancangan tugas; dan (4) penilaian serta balas jasa atas prestasi.

Terdapat empat unsur kekuatan organisasi dalam menyelenggarakan tugas pokok dan fungsinya yaitu penilaian prestasi kerja, struktur organisasi, gaya kepemimpinan, dan sarana organisasi.

Penilaian Prestasi Kerja. Dalam rangka pengembangan sumber daya manusia, penilaian prestasi kerja sangat penting artinya karena setiap individu dalam suatu organisasi ingin mendapatkan penghargaan dan perlakuan yang adil dari pimpinan.

Gaya kepemimpinan. Dalam mengelola suatu organisasi diperlukan seorang pemimpin sebagai pengendali jalannya organisasi. Gaya dari tipe serta kebijakan yang diambil oleh seorang pemimpin sangat mempengaruhi suasana dalam lingkungan organisasi untuk mencapai tujuan. Masalah kepemimpinan akan selalu hidup dan digali pada setiap generasi guna mencari formulasi sistem kepemimpinan yang tepat. Hal ini mengindikasikan bahwa paradigma kepemimpinan adalah sesuatu yang sangat dinamis dan memiliki kompleksitas yang tinggi.

Berdasarkan hal tersebut di atas, dapat disimpulkan bahwa seorang pemimpin memiliki gaya dan tipe yang berbeda. Kepemimpinan pada umumnya distimulir oleh dorongan kuat dari dalam diri untuk memimpin, menciptakan gairah kerja, loyal dan bermoral dan berdedikasi tinggi serta dapat membangkitkan kekuatan rasional dan kekuatan emosional. 
Vol.2 No.1. April 2019. pp.65-78. Copyright@2019 Journal PUBLICUHO Faculty of Social and Political Sciences Halu Oleo University, Kendari, Southeast Sulawesi, Indonesia. e-ISSN: 2621-1351. Open Access at:

http://ojs.uho.ac.id/index.php/PUBLICUHO

Jounal publiuho is licensed under a Creative Commons Attribution 4.0 International License, which permits unrestricted use, distribution, and reproduction in any medium, provided the original work is properly cited.

Struktur organisasi. Perkembangan ilmu dan teknologi yang begitu pesat membawa dampak pada perkembangan organisasi untuk mengadakan perubahan ataupun pembaharuan terhadap bentuk struktur organisasi.

Struktur organisasi adalah kerangka atau susunan unit atau satuan kerja atau fungsi-fungsi yang dijabarkan dari tugas atau kegiatan pokok suatu organisasi, dalam usaha mencapai tujuannya. Setiap unit mempunyai posisi masing-masing karena itu ada unit yang berbeda tingkatannya dan ada pula yang sama.

Veithzal Rivai (2004 : 408) mengemukakan bahwa yang dimaksud dengan struktur adalah pola interaksi yang ditetapkan dalam suatu organisasi sedangkan struktur organisasi adalah pola formal mengelompokkan orang dan pekerjaan, pola formal aktivitas dan hubungan antara berbagai sub unit organisasi yang sering digambarkan melalui bagan organisasi.

Struktur organisasi mengandung 6 unsur utama yang merupakan satu kesatuan yang tidak dapat dipisahkan antara satu dengan yang lainnya yaitu : (1) spesialisasi kerja; (2) departementalisasi; (3) rantai komando; (4) rentang kendali; (5) sentralisasi dan desentralisasi; dan (6) formalisasi.

Gaya kepemimpinan. Dalam mengelola suatu organisasi diperlukan seorang pemimpin sebagai pengendali jalannya organisasi. Gaya dari tipe serta kebijakan yang diambil oleh seorang pemimpin sangat mempengaruhi suasana dalam lingkungan organisasi untuk mencapai tujuan. Masalah kepemimpinan akan selalu hidup dan digali pada setiap generasi guna mencari formulasi sistem kepemimpinan yang tepat. Hal ini mengindikasikan bahwa paradigma kepemimpinan adalah sesuatu yang sangat dinamis dan memiliki kompleksitas yang tinggi.

Sarana organisasi. Dalam aktivitas organisasi diperlukan adanya sarana organisasi sebagai faktor penunjang dalam keberhasilan pencapaian tujuan organisasi.

Mempertegas tulisan ini, iklim organisasi menurut Litwin dan Stringers, seperti dikutip oleh Muhammad (2002 : 83), yang menilai komponen-komponen iklim organisasi : (a) Rasa tanggung jawab, (b) standar atau harapan tentang kualitas pekerjaan, (c) Ganjaran (reward), (d) Rasa persaudaraan, dan (e) Semangat tim. Bertolak dari pendapat ini, Muhammad (2002 : 83) menyimpulkan bahwa iklim organisasi dapat dipelajari dengan mengobservasi komponen-komponennya yaitu (a) Otonomi individu, Kebebasan yang dialami individu, (b) Orientasi ganjaran dari organisasi, (c) Tingkat kejelasan struktur dan posisi pada anggota, dan (d) Banyaknya sokongan (dukungan).

\section{Konsep Kinerja}

Istilah kinerja (performance), menurut LAN (1992) seperti dikutip oleh Muhammad Kasim (2006 : 237), pada dasarnya berarti prestasi kerja, pelaksanaan kerja, pencapaian kerja atau penampilan kerja. Baso (2003), seperti dikutip pula oleh Muhammad Kasim (2006 : 237), mendefenisikan kinerja sebagai suatu hasil dimana orang atau sumber-sumber dan pada lingkungan kerja tertentu secara bersama-sama. membawa hasil akhir yang didasarkan pada tingkat mutu dan standar yang telah ditetapkan. Menempatkan organisasi sebagai unit analisis, Marshall W. Meyer (1994: 556) mengemukakan bahwa kinerja menggambarkan seberapa baik atau buruk sebuah organisasi bekerja.

Meyer memaparkan kinerja menurut Teori Organisasional Kontemporer. Dua teori turunan dari teori besar ini, yaitu. Teori Institusional dan Teori Evolusi. Meninjau perspektif Teori Institusional tentang Kinerja, Meyer (1994: 560) menyarikan tiga proposisi, satu proposisi kunci diantaranya adalah : "Organizations not seeking efficiency outcome (but) seek legitimacy by conforming to expectation as to how they ought rationally to represent their formal structure and process; " berarti menawarkan legitimasi sebagai alternatif fungsional terhadap, efisiensi sebagai ukuran kinerja. Meyer (1994: 560) menegaskan bahwa organisasi-organisasi institusional disetir oleh proses-proses sosial, sedangkan organisasi-organisasi teknis oleh kalkulus efisiensi. 
Meninjau kontribusi teori itu dibagi studi kinerja organisasional. Pertama, menderivasi beberapa prinsip standar ukuran akunting dan finansial, menawarkan ukuran kinerja yang terkait dengan survival organisasional, yaitu kinerja lampau kumulatif (cumulative past performance) dan pertumbuhan langsung (current growth), serta daya lenting (resilience), kesiapan (readiness atau preparedness) akan kemungkinan dimasa depan; semua itu tidak menyumbang sesuatu yang penting kepada profitabilitas langsung dan kinerja keuangan. Kedua, menawarkan ukuran kendala kinerja, ukuran yang berguna untuk mengadaptasi kinerja secara berkesinambungan.

Selanjutnya Etzioni (1985 : 13) mengemukakan bahwa pengukuran efektivitas dan efisiensi menimbulkan problem. Apabila tujuan bersifat kontinyu pengukuran efektivitasnya lebih rumit. Hal lain, organisasi yang masukannya tidak berbentuk material, pengukuran efektivitasnya sangat sulit. Begitu pula pengukuran efisiensi atau berkaitan dengan itu misalnya masukan, produktivitas dan biaya.

Begrhungan dengan itu, pengelolaan suatu organisasi yang diselenggarakan oleh pemerintah pada hakekatnya merupakan satuan kegiatan untuk mencapai suatu tujuan tertentu. Dalam pencapaian tujuan tersebut unsur aparatur sangat penting peranannya karena secara prinsip aparatur merupakan salah satu unsur penting dalam organisasi.

Nawawi (1993 : 29) mengemukakan bahwa aparatur adalah manusia yang secara individual telah dibentuk oleh kehidupan sosial budaya sekitarnya yang berbeda-beda antara satu dengan yang lain. Kondisi sosial budaya ternyata merupakan faktor yang memberi warna terhadap sikap, pikiran, dan tindakan dalam kehidupan sehari-hari. Perlu disadari bahwa pelaksanaan aktifitas aparatur masih banyak menghadapi tantangan yang memerlukan perhatian dan analisis pemikiran dalam memecahkan masalah yang ada. Aparatur yang seharusnya berperan sebagai abdi masyarakat sering terabaikan di mana lebih menekankan pada aspek memberikan perintah atau sebagai penguasa daripada melayani, memfasilitasi maupun membantu dan mempermudah masyarakat dalam menyelesaikan urusan kemasyarakatan.

Pengukuran kinerja haruslah memperhatikan unsur-unsur sebagai berikut : (1) biaya yang dikeluarkan seyogyanya tidak lebih besar dari manfaat yang diterima; (2) dimulai dari awal program; (3) terkait langsung dengan tujuan strategis; (4) sederhana serta memunculkan data yang mudah digunakan; (5) dapat diulang secara terus menerus, sehingga dapat diperbandingkan antara pengukuran pada satu titik waktu dengan waktu lainnya; (6) dilakukan pada system secara keseluruhan yang menjadi lingkup program; (7) digunakan untuk menetapkan target yang mengarah pada peningkatan kinerja yang akan datang; (8) ukuran kinerja harus dipahami secara jelas oleh setiap individu yang terlibat; (9) pelibatan setiap individu dalam setiap pengukuran kinerja; (10) pengukuran kinerja harus memenuhi persyaratan reliabilities dan validitas; dan (1l) pengukuran harus berfokus pada tindakan korektif dan peningkatan, bukan sekedar pada pemantauan atau pengendalian.

Pegg (1994 : 146) mengemukakan bahwa mencintai dan menekuni pekerjaan semacam kontrol mutu dalam benak seseorang sehingga orang itu secara otomatis melakukan pekerjaan dengan lebih cermat, berminat dengan profesionalisme menghasilkan kinerja yang memuaskan.

Mengacu pada pendapat tersebut di atas jelaslah bahwa konsep kinerja menekankan pada empat aspek yaitu : (l) aspek pencapaian sesuatu; (2) adanya prestasi yang ditunjukkan; (3) kemampuan dalam bekerja baik secara individu maupun dalam bentuk kelompok pada suatu organisasi yang menekankan output pelaksanaan tugas atau pekerjaan itu sendiri; dan (4) penampilan hasil karya personil baik kualitas maupun kuantitasnya dalam organisasi. Mencermati berbagai pendapat tersebut di atas, maka dapatlah disimpulkan bahwa kinerja aparatur adalah kemampuan seorang aparatur mengaktualisasikan segala potensi yang dimiliki dalam melaksanakan tugas pokok dan fungsinya guna mencapai tujuan organisasi secara efektif dan efisien.

Dwiyanto (2002 : 48-49) mengemukakan beberapa indikator yang dapat digunakan dalam mengukur kinerja birokrasi publik, yaitu sebagai berikut: 
1. Produktivitas, konsep produktivitas tidak hanya mengukur tingkat efisiensi, tetapi juga efektivitas pelayanan. Produktivitas pada umumnya dipahami sebagai rasio antara output dan input.

2. Kualitas layanan, isu mengenai kualitas layanan cenderung menjadi semakin penting dalam menjelaskan kinerja organisasi publik. Banyak pandangan negatif mengenai organisasi publik muncul karena ketidakpuasaan masyarakat terhadap kualitas layanan yang diterima dari organisasi publik.

3. Responsivitas adalah kemampuan organisasi untuk mengenali kebutuhan masyarakat, menyusun agenda dan prioritas pelayanan serta mengembangkan program-program pelayanan publik sesuai dengan kebutuhan dan aspirasi masyarakat.

4. Responsibilitas, menjelaskan apakah pelaksanaan kegiatan organisasi publik itu dilakukan sesuai dengan prinsip-prinsip administrasi yang benar atau sesuai dengan kebijakan organisasi, baik yang eksplisit maupun yang implicit. .

5. Akuntabilitas, menunjuk pada seberapa besar kebijakan dan kegiatan organisasi publik tunduk pada para pejabat politik yang dipilih oleh rakyat. Asumsinya adalah bahwa para pejabat politik tersebut dipilih oleh rakyat, sehingga dengan sendirinya akan selalu mempresentasikan kepentingan rakyat. .

Pandangan Dwiyanto (2002 : 48-49) tersebut memberikan gambaran bahwa ukuran kinerja organisasi mencakup segala aspek yang terkait dengan aktivitas organisasi, mulai dari aspek perencanaan, kebijakan sampai pada aktivitas pelayanan yang harus dilaksanakan oleh pegawai dalam kedudukannya sebagai anggota organisasi.

\section{Penggunaan Penilaian Kinerja Bagi Pegawai}

Penilaian kinerja (performance appraisal) adalah proses evaluasi seberapa baik pegawai mengerjakan pekerjaan mereka ketika dibandingkan dengan satu set standar, dan kemudian mengkomunikasikannya dengan para pegawai. Penilaian demikian ini juga disebut sebagai penilaian pegawai, evaluasi pegawai, tinjauan kinerja, evaluasi kinerja, dan penilaian hasil. Riset menunjukkan penggunaan peniiaian kinerja yang luas untuk mengadministrasi honor dan gaji, memberikan umpan balik kinerja, dan mengidentifikasikan kekuatan dan kelemahan pegawai.

Penilaian kinerja kadang-kadang merupakan kegiatan manajer yang paling tidak disukai, dan mungkin ada beberapa alasan untuk perasaan demikian. Tidak semua peniiaian kinerja bersifat positif, dan mendiskusikan nilai dengan pegawai yang nilainya buruk bisa menjadi lidak menyenangkan. Penilaian kinerja pegawai memiliki dua penggunaan yang umum di dalam organisasi, dan keduanya bias merupakan konflik yang potensial. Salah satu kegunaan adalah mengukur kinerja untuk tujuan memberikan penghargaan atau dengan kata lain untuk membuat keputusan administratif mengenai si pegawai. Promosi atau pemecatan pegawai bisa tergantung pada hasil peniiaian kinerja, yang sering membuat peniiaian kinerja menjadi sulit untuk dilakukan oleh para manajer.

\section{Kerangka Pemikiran}

\begin{tabular}{|l|l|l|}
\hline IKLIM ORGANISASI & \multicolumn{1}{|l|}{ KINERJA PEGAWAI } \\
1. Otonomi Individu & \\
2. Orientasi Ganjaran & 1. Produktivitas \\
3. Kejelasan Struktur & 2. Kualitas Layanan \\
4. Dukungan & 3. Daya Tanggap \\
Muhammad (2002: 83) & 4. Tanggungjawab \\
& 5. Pertanggun \\
& Dwiyanto (2002: 49-49) \\
\hline
\end{tabular}

Gambar 1 : Kerangka Pikir Penelitian 


\section{METODE PENELITIAN}

Desain penelitian yang digunakan dalam penulisan tesis ini adalah dengan menggunakan penelitian survey yaitu untuk mendapatkan keterangan yang jelas terhadap masalah dalam penelitian ini. Dalam penelitian ini dilakukan uji statistic verifikatif terhadap hubungan antara variabel. Penelitian ini dilakukan dengan mengumpulkan data kualitatif dan selanjutnya akan disajikan dalam bentuk angka untuk diuji secara verifikatif sesuai dengan rancangan analisis data.

\section{Variabel Penelitian}

Dari kerangka pemikiran dan hipotesis penelitian sebagaimana yang dikemukakan diatas, maka variabel penelitian ini adalah iklim organisasi yang diberi symbol x sebagai variabel bebas (independent variable) dan kinerja pegawai diberi symbol y sebagai variabel terikat (dependent variable).

\section{Populasi dan Sampel}

Dalam penulisan ini yang menjadi populasi adalah seluruh pegawai pada Fakultas Ilmu Sosial dan Ilmu Politik Universitas Haluoleo yang terdiri atas 22 orang PNS dan 30 orang Pegawai Harian Tetap (PHT). Penentuan sampel menggunakan metode total sampling. Total sampling dilakukan karena mengingat jumlah populasi yang relatif kecil (Soeratno dan Arsyad, 1999: 119-120). Sehingga jumlah sampel yang menjadi responden dalam penelitian ini seluruhnya adalah 53 ditambah dengan informan dari pihak pimpinan Fakultas dan Jurusan.

\section{Teknik Analisa Data}

Untuk menganalisis Iklim organisasi yang berlaku akan digunakan rata-rata tertimbang pada skor masing-masing indikator yang kemudian ditentukan kategorinya berdasarkan 5 kategori (skala 5) berdasarkan pendapat Sutrisno Hadi (1989 : 12) sebagai berikut :

$$
\begin{aligned}
\text { Inteval Kategori } & =\frac{\text { Jarak Pengkuran }(R)}{\text { Jumlah Interval }} \\
= & \frac{\text { Skor Tertinggi }- \text { skor terendah }}{\text { Kriteria }} \\
= & \frac{5-1}{5}=0,8
\end{aligned}
$$

Sehingga dari perhitungan tersebut diperoleh batas intervalnya sebagai berikut:

$$
\begin{aligned}
1,00-1,80 & =\text { kategori sangat rendah } \\
1,81-2,60 & =\text { kategori rendah } \\
2,61-3,40 & =\text { kategori sedang } \\
3,41-4,20 & =\text { kategori tinggi } \\
4,21-5,00 & =\text { kategori sangat tinggi. }
\end{aligned}
$$

Sedangkan untuk menguji pengaruh variable iklim organisasi $(\mathrm{X})$ terhadap variable kinerja pegawai $(\mathrm{Y})$ akan digunakan uji regresi linear sederhana sebagai berikut:

$$
\mathrm{Y}=\mathrm{a}+\mathrm{bx}
$$


Sedangkan a dan b dapat dihitung sebagai berikut:

$$
\begin{aligned}
\mathrm{a} & =\frac{(\Sigma \mathrm{Y})\left(\sum \mathrm{X}^{2}\right)-(\Sigma \mathrm{X})(\Sigma \mathrm{XY})}{\mathrm{n} \Sigma \mathrm{X}^{2}-(\Sigma \mathrm{X})^{2}} \\
\mathrm{~b} & =\frac{\mathrm{n} \Sigma \mathrm{XY}-\left(\sum \mathrm{X}\right)(\Sigma \mathrm{Y})}{\mathrm{n} \Sigma \mathrm{X}^{2}-\left(\sum \mathrm{X}\right)^{2}}
\end{aligned}
$$

Berkenaan dengan hubungan antara variabel bebas dengan variabel terikat, penulis akan mengurai hubungan antara masing-masing indikator iklim organisasi dengan kinerja untuk menggambarkan adanya hubungan antara variabel, yang diukur dengan koefisien korelasi yang dideskripsikan atau dikualitatifkan.

Rumus korelasi yang digunakan adalah rumus korelasi Product Moment (r) Pearson (Sugiono, 1998 : 148) dengan rumus :

$$
\begin{aligned}
r_{y x} & =\frac{\sum x y}{\sqrt{\left(\sum x^{2}\right)\left(\sum y^{2}\right)}} \\
r & =\text { koefisien korelasi } \\
\mathrm{x} & =\text { skor kesesuaian Iklim organisasi } \\
\mathrm{Y} & =\text { skor kinerja }
\end{aligned}
$$

\section{HASIL DAN PEMBAHASAN}

\section{Analisa Variabel Iklim Organisasi}

Dalam rangka mendapatkan data untuk dianalisis, dilakukan skoring terhadap jawaban responden dengan, skala Likert sebagaimana dijelaskan pada bab terdahulu. Selanjutnya dilakukan analisa deskriptif terhadap jawaban dimaksud. Analisis deskriptif ini dimaksudkan untuk menafsirkan skor-skor berdasarkan butir pertanyaan yang ada dalam variabel-variabel penelitian yang dilakukan.

Skor dalam tiap butir pernyataan dicari rata-rata tertimbangnya dan dianalisis menurut kategori masingmasing. Hal tersebut dilakukan untuk mengetahui gambaran kenyataan Iklim Organisasi yang berlaku Fakultas Ilmu Sosial dan Ilmu Politik

Data yang diperoleh merupakan rata-rata tertimbang dari masing-masing variabel baik iklim organisasi maupun kinerja pegawai yang dibahas pada sub-bab kemudian, dengan asumsi bahwa jawaban responden dinyatakan dalam angka (skor) dan setiap angka menunjukkan tingkatan interval l - 5 maka untuk menentukan kategori ditentukan 5 kategori (skala 5) berdasarkan perhitungan interval (Sutrisno Hadi, 1989:12) sebagaimana dijelaskan pada metodologi penelitian.

\section{Kenyataan Iklim Organisasi}

Untuk menganalisis iklim organisasi, terlebih dahulu digambarkan, bagaimana iklim organisasi yang dimiliki Fakultas Ilmu Sosial dan Ilmu Politik secara umum berdasarkan karakteristik iklim organisasi. Berkenaan dengan kenyataan iklim organisasi ini, penulis menggunakan skala 1 sampai dengan 5, yang menunjukkan penilaian atau persepsi pegawai mengenai kenyataan iklim organisasi yang dilihatnya sehingga terdapat gambaran kontinum dari tiap-tiap karakteristik iklim organisasi. Sangat setuju (nilai 5) pada tiap pernyataan pada masing-masing karakteristik menunjukkan karakteristik tersebut berada pada kontinum yang sangat tinggi, sedangkan sangat tidak setuju (nilai l) menunjukkan karakteristik tersebut berada pada kontinum yang sangat rendah. 


\section{Penilaian Iklim Organisasi}

Berdasarkan data yang disajikan pada karakteristik-karakteristik tersebut, dapat disajikan rekapitulasi atas rata-rata tertimbang dapat dilihat pada Tabel 1 berikut:

Tabel l. Rekapitulasi Rata - Rata Tertimbang Iklim Organisasi.

\begin{tabular}{|c|l|c|c|}
\hline No. & \multicolumn{1}{|c|}{ Karakteristik } & Budaya & Kategori \\
\hline 1 & Otonomi Individu & 3,40 & Sedang \\
\hline 2 & Orientasi janjaran & 2,83 & Sedang \\
\hline 3 & Kejelasan Struktur & 3,37 & Sedang \\
\hline 4 & Dukungan & 3,28 & Sedang \\
\hline \multicolumn{2}{|l|}{ Rata-rata tertimbang } & 3,22 & Sedang \\
\hline
\end{tabular}

Sumber : Pengolahan Data dari jawaban kuesioner, 2011.

\section{Analisis Variabel Kinerja Pegawai}

Dalam menganalisis besarnya pengaruh iklim organisasi terhadap kinerja pegawai, akan dijelaskan terlebih dahulu bagaimana melahirkan kinerja pegawai dengan melihat hasil penilaian jawaban responden terhadap kuesioner Kinerja Pegawai berdasarkan indikator-indikator yang terdiri dari Produktivitas, kualitas layanan, Daya Tanggap, Tanggungjawab dan Pertanggungjawaban. Untuk menilai kepuasan kerja tersebut, penulis menggunakan skala 1 sampai dengan 5 pada masing-masing item pernyataan yang menunjukkan nilai dari sangat rendah sampai dengan sangat tinggi. Selanjutnya dicari rata-rata tertimbangnya untuk dapat menentukan kategorinya dengan merujuk kepada kategori yang dijelaskan pada sub bab iklim organisasi.

Berdasarkan data yang disajikan pada indikator-indikator kinerja pegawai tersebut, dapat disajikan rekapitulasi atas rata-rata tertimbang sebagaimana dijelaskan pada tabel 2 berikut :

Tabel 2. Rekapitulasi Penilaian terhadap Kinerja Pegawai

\begin{tabular}{|c|l|c|c|}
\hline No. & \multicolumn{1}{|c|}{ Indikator } & Rata-rata Tertimbang & Kategori \\
\hline I & Produktivitas & 3,39 & Sedang \\
\hline 2 & Kualitas Layanan & 3,32 & Sedang \\
\hline 3 & Daya Tanggap & 3,26 & Sedang \\
\hline 4 & Tanggungjawab & 3,39 & Sedang \\
\hline 5 & Pertanggungjawaban & 3,34 & Sedang \\
\hline \multicolumn{2}{|l|}{ Rata-rata Tertimbang keseluruhan } & 3,34 & Sedang \\
\hline
\end{tabular}

Sumber : Data yang diolah dari jawaban kuesioner, 2011

Dari tabel 2 tersebut dapat dijelaskan bahwa rata-rata pegawai Fakultas Ilmu Sosial dan Ilmu Politik memiliki Produktivitas, Kualitas layanan, Daya tanggap, tanggungjawab dan pertanggungjawaban yang dihasilkan pegawai dalam kategori sedang. Berdasarkan indikator-indikator tersebut, secara umum dapat disimpulkan bahwa rata-rata pegawai Fakultas Ilmu Sosial dan Ilmu Politik memiliki kinerja.cukup baik.

\section{Pengujian Hipotesis.}

Analisis distribusi jawaban responden menurut skor variabel X dan Y yang diuraikan ke dalam dimensi telah dipaparkan pada tabel-tabel sebelumnya, baik analisis variabel X dan Y. Dari tabel-tabel tersebut dapat diketahui bahwa baiknya iklim organisasi diikuti pula oleh tingginya kinerja pegawai, namun demikian sebagai dasar untuk penarikan kesimpulan pengaruh variabel $\mathrm{X}$ terhadap $\mathrm{Y}$ harus menggunakan tehnik statistik. Sebagaimana telah diutarakan dalam Bab III mengenai metode analisis untuk menguji hipotesis yang diajukan 
Vol.2 No.1. April 2019. pp.65-78. Copyright@2019 Journal PUBLICUHO Faculty of Social and Political Sciences Halu Oleo University, Kendari, Southeast Sulawesi, Indonesia. e-ISSN: 2621-1351. Open Access at:

http://ojs.uho.ac.id/index.php/PUBLICUHO

Jounal publiuho is licensed under a Creative Commons Attribution 4.0 International License, which permits unrestricted use, distribution, and reproduction in any medium, provided the original work is properly cited.

dalam penelitian ini, yakni besar pengaruh iklim organisasi terhadap kinerja pegawai Fakultas Ilmu Sosial dan Ilmu Politik.

\section{Pembahasan}

Berdasarkan hasil olahan data dari jawaban responden tentang kenyataan organisasi di Fakultas Ilmu Sosial dan Ilmu Politik menunjukan bahwa iklim organisasi pada karateristik otonomi individu, orientasi ganjaran, kejelasan struktur dan dukungan dalam melaksanakan tugas masih kurang optimal dilaksanakan sehingga mengakibatkan iklim organisasi di Fakultas Ilmu Sosial dan Ilmu Politik kurang kondusif artinya Iklim organisasi berpengaruh signikan terhadap kinerja pegawai..

Dari hasil analisis pengaruh variabel bebas $(\mathrm{X})$ terhadap variabel terikat $(\mathrm{Y})$ melalui program SPSS for windows versi 15.00 diperoleh hasil dapat diketahui besar koefisien korelasi $X$ terhadap $Y$ adalah $(r=0,634)$. Hasil tersebut jika disesuaikan dengan tafsiran koefisien korelasi dalam Sugiyono (2003: 216) adalah kuat karena berada, di antara. 0,60<r $<0,799$.

Dari hasil tersebut diketahui iklim organisasi berpengaruh besar dan positif terhadap kinerja pegawai, selanjutnya apabila akan digeneralisasikan kepada populasi harus dilakukan uji signifikansi. Berdasarkan uji signifikansi dengan derajat kesalahan $5 \%$ dengan uji dua pihak $\mathrm{dk}=\mathrm{n}-2=5 \mathrm{l}$, maka pengujian ini dilakukan dengan uji $t$, dari hasil tersebut diperoleh $t$ hitung 5,850. Letak $t$ hitung apabila dikonfirmasikan dengan kurva titik kritis dan daerah penolakan Ho adalah ternyata t hitung $(2,000)$ jatuh di sebelah titik kritis atau $t$ tabel sebesar $(2,000)$ atau jatuh di daerah penolakan Ho. Apabila $t$ hitung $>t$ tabel maka pengujian signifikan, berarti dapat diperlakukan kepada semua populasi. Karena 5,850 >2,000 berarti signifikan dengan demikian Ho ditolak dan Ha. diterima.

Berdasarkan deskripsi data dan uraian tersebut, dapat digambarkan bahwa terdapat hubungan yang erat/kuat antara iklim organisasi dan kinerja. Hal tersebut memberi gambaran bahwa apabila ingin meningkatkan kinerja pegawai perlu memperhatikan iklim organisasi. Perhatian tersebut terutama dititikberatkan kepada karakteristik otonomi individu. Kesesuaian tersebut dapat dicapai apabila nilai-nilai inti organisasi yang diharapkan (hal ideal) para pegawainya dapat lebih diinternalisasikan kepada pegawai sehingga dapat mendorong kepada dipegang teguhnya nilai-nilai inti organisasi.

Hal tersebut relevan dengan pendapat Simora (1997 : 81) bahwa iklim organisasi adalah lingkungan atau psikologi organisasi. Artinya bahwa untuk melahirkan kinerja atau produktivitas kerja pegawai secara psikologi dibutuhkan adanya kebebasan berpendapat dalam hal pelaksanaan tugas, kebebasan untuk berinisiatif dalam melakukan pekerjaan dan tidak adanya tekanan dalam melakukan pekerjaan

Olahan kuesioner maupun jawaban informan memberikan gambaran bahwa dukungan sangat berpengaruh terhadap kinerja pegawai di Fakultas Ilmu Sosial dan Ilmu Politik. Namun dalam kenyataannya menunjukan kurang mendorong lahirnya kinerja pegawai dalam melakukan tugas pekerjaannya. Sehubungan dengan hal tersebut menurut penulis bahwa untuk menciptakan kinerja pegawai di Fakultas Ilmu Sosial dan Ilmu Politik perlu dilakukan atau memberikan dukungan sepenuhnya kepada individu agar pegawai dapat menunjukan kinerjanya secara optimal. Ini artinya bahwa iklim organisasi (dukungan) memiliki pengaruh yang kuat dalam membentuk organisasi yang memiliki kinerja tinggi atau dengan kata lain iklim organisasi yang kondusif dapat melahirkan kinerja terhadap anggotanya.

Dari uraian tersebut baik dari olahan kuesioner maupun jawaban informan memberikan gambaran bahwa iklim organisasi pada, karakteristik dukungan berpengaruh terhadap kinerja pegawai di Fakultas Ilmu Sosial dan Ilmu Politik. Namun dalam kenyataan menunjukan belum maksimalnya dukungan pimpinan organisasi untuk meningkatkan kinerja pegawai dalam melakukan pekerjaannya. Sehubungan dengan hal tersebut menurut penulis bahwa untuk menciptakan kinerja pegawai di Fakultas Ilmu Sosial dan Ilmu Politik perlu dilakukan atau memberikan dukungan artinya bahwa agar pegawai dapat menunjukan kinerjanya maka harus ada upaya pimpinan organisasi dalam membangun iklim organisasi dalam kesempatan untuk mengikuti diklat dalam 
meningkatkan kemampuan dalam melaksanakan tugas-tugasnya, pimpinan harus selalu memberikan penjelasan tentang posisi kerja dan pimpinan harus memberikan pemahaman tentang tugas secara detail dan terperinci.

Temuan Hasil Penelitian bahwa Iklim Organisasi berpengaruh positif dan signifikan terhadap kinerja pegawai hasil penelitian ini juga mendukung penelitian yang dilakukan oleh Saiful mengenai Analisis Kinerja Pegawai dalam Pelayanan Administrasi Kepegawaian. Semakin baik Iklim organisasi maka akan semakin baik pula kinerjanya., Temuan Penelitian ini juga sejalan dengan teori yang dikemukakan oleh Gibson (1989:5) bahwa iklim organisasi yang baik sangat mendukung kinerja staf dalam organisasi, dimana setiap staf dapat melaksanakan tugas dan kewajibannya dengan secara optimal.

Sesuai Hasil Uji Hipotesis, secara simultan dketahui bahwa Iklim organisasi memiliki pengaruh yang besar terhadap kinerja pegawai pada Fakultas Ilmu Sosial dan Ilmu Politik Universitas Haluoleo. Artinya dengan iklim yang kondusif tercermin pada adanya otonomi individu, orientasi ganjaran, Kejelasan Struktur dan adanya dukungan menyebabkan semakin tingginya kinerja apabila dilihat dari dimensi Produktivitas, kualitas layanan, daya tanggap, tanggungjawab dan pertanggungjawaban. Adapun pengaruh besaran iklim organisasi terhadap kinerja pegawai dengan nilai koefisien regresi sebesar 0,634 selebihnya dipengaruhi oleh faktor lain yang tidak dimasukan dalam penelitian ini. Faktor lain yang dimaksud misalnya motivasi, disiplin, gaya kepemimpinan dan kompetensi.

\section{KESIMPULAN}

Berdasarkan Hasil dan Pembahasan, maka dapat ditarik kesimpulan sebagai berikut :

1. Bahwa Iklim organisasi di Fakultas ilmu Sosial dan Ilmu Politik Universitas Haluoleo dari hasil penelitian pada karakteristik otonomi individu menunjukan pada kategori Sedang, orientasi ganjaran dan kejelasan struktur sama-sama berada dalam kategori sedang, sedangkan karakteristik dukungan termasuk dalam kategori Sedang. Namun secara keseluruhan setelah dirata-ratakan kondisi iklim organisasi di Fakultas Ilmu Sosial dan Ilmu Politik Universitas Haluoleo menunjukan atau berada pada kategori Sedang. Artinya iklim organisasi di Fakultas Ilmu Sosial dan Ilmu Politik Universitas Haluoleo selama ini kurang begitu kondusif. Kondisi atau iklim organisasi tersebut berpengaruh kuat dan signifikan terhadap rendahnya kinerja pegawai di Fakultas Ilmu Sosial dan Ilmu Politik.

2. Dari hasil penelitian menunjukkan bahwa semakin baik dan kondusif iklim organisasi di Fakultas Ilmu Sosial dan Ilmu Politik maka akan semakin tinggi pula kinerja pegawai ini artinya Iklim organisasi berpengaruh positif dan signifikan terhadap kinerja pegawai Oleh karenanya, Hipotesis yang diajukan penulis diterima.

\section{SARAN}

Berdasarkan kesimpulan dari pembahasan, maka penulis menyarankan beberapa hal sebagai berikut:

1. Fakultas Ilmu Sosial dan Ilmu Politik Universitas Haluoleo melalui kebijakan yang dikeluarkan agar lebih memperhatikan perbaikan iklim organisasi yang berorientasi pada peningkatan kinerja yang bermuara pada pencapaian produktivitas pegawai.

2. Dalam rangka melahirkan kinerja pegawai atau produktivitas kerja pegawai maka perlu dilakukan usaha membangun dan menciptakan iklim organisasi yang baik dan kondusif, artinya Fakultas Ilmu Sosial dan Ilmu Politik Universitas Haluoleo perlu memperhatikan serta menerapkan faktor-faktor iklim organisasi yang dapat mempengaruhi kinerja pegawai, yakni : otonomi individu, orientasi ganjaran, kejelasan struktur, dan dukungan. 


\section{DAFTAR PUSTAKA}

Arikunto Suharsimi, 1993. Prosedur Penelitian : Suatu Pendekatan Praktek, Edisi kedua, Jakarta : PT Rineka Cipta.

Blau, Peter M. dan Mardhall W. Meyer, 1987. Birokrasi dalam Masyarakat Modern

(Penerjemahan ; Gary R. Yusuf), Edisi ke-2. Jakarta : UI-Press.

Dwiyanto,Agus, 2002. Penilaian Kinerja Organisasi Pelayanan Publik. FISIP UGM, Yogyakarta

Dwiyanto, 2006 Reformasi Birokrasi Pelayanan publik di Indonesia. Pusat Studi Kependudukan dan Kebijakan UGM Yogyakarta.

Etzioni, Amitai, 1985. Organisasi-organisasi Modern (Penerjemah : Seryatim), Cetakan ke-2. Jakarta: UI-Press.

Gibson, James L, dkk. 1984. Organisasi dan Manajemen (Prilaku, Struktur dan Proses). Jakarta Edisi Keempat, Terjemahan : Penerbit Erlangga, Jakarta

Gibson, James. 1986. Organisasi Prilaku, Struktur dan Proses. Diterjemahkan oleh Djoerban Wahid. Erlangga Jakarta.

Gibson, James L,. John M. Ivencevich, dan james Donnely, 1994. Organisasi dan Manajemen : Perilaku, Struktur dan Proses (penerjemahan L Nonuk Adriani). Jakarta L Erlangga.

Hadi Sutrisno, 1989. Statistik I, Yogyakarta : Andi Offset

Kasim, Muhammad, 2006. "Tinjauan Analisis Kinerja kebijakan dan Pelayanan Publik," Di dalam Bekerja demi rakyat : Meningkatkan Kompetensi Aparatur Daerah dalam Kebijakan dan Pelayanan Publik, ed Didi Marzuki, 235-250, Cetakan I. Jakarta: Komunal.

Keputusan Menteri Pendayagunaan Aparatur Negara RI Nomor 25/KEP/M.PAN/04/2002 tentang Pedoman Pengembangan Budaya Kerja Aparatur Negara Jakarta.

I.Manullang, 1990. Management Personalia, Cetakan Keduabelas. Jakarta : Ghalia Indonesia.

Meyer, Marshall W. 1994. "Measuring Performance in Economic Organization" [Pengukuran Kinerja pada Organisasi Ekonomik]. Di dalam The Handbook of Economic Sociology, eds. Neil J. Smelser dan Richard Swedberg, 556-578, Cetakan ke-10. New Kersey, U.S.A. : Princetion University Press.

Muhammad, Arni, 2002. Komunikasi Organisasi. Jakarta : Bina Aksara.

Nawawi Hadari, 1998. Manajemen Sumber Daya Manusia, Cetakan Kedua, Yogyakarta : Gajah Mada University Press.

Robbins, P Stephen , 1990 Organization Theory, Structure, Design and Application, Third Edition, New-Jersey, USA : Prentice-Hall International Edition. 
1993. Organizational Behavior, $6^{\text {th }}$ Edition, Englewood Cliff, New Jersey, USA : Prentice-Hall International Edition : terjemahan, jilid I, 2001 dan jilid II, 1996. Perilaku Organisasi, Penerjemah : Hedyana Pujaatmaka, Jakarta : Prenhallindo.

Robbins, Stephen P. 2001. Perilaku Organisasi : Konsep, Kontroversi, Aplikasi (penerjemah : Hadyana Pujatmaka dan Benyamin Molan), Jilid 2, Catatn ke-10. Jakarta : Prenhallindo.

Singarimbun Masri dan Effendi Sofian, 1984. Metode Penelitian Survai, Edisi keempat, Jakarta: LP3S.

Schein, Edgar H., 1992. Organization Culture and Leadership, Second Edition, San Francisco, USA : The JosseyBass Publishers.

Sujana, 1996. Teknik Analisis Regresi dan Korelasi. Bandung : Bina Cipta Sugiyono, , 1998. Metode Penelitian Administrasi, Bandung : Alfabeta Sugiyono, 2002. Metode Penelitian Administrasi. Bandung : CV, Alfabeta

Sutarsono, 1984. Dasar-dasar Organisasi. Cetakan Keenam. Yogakarta : Gajah Mada University Press.

Supriyadi Gering dan Guno Tri., 2003. Budaya Kerja Organisasi Pemerintah, LAN RI, Jakarta: LAN. Steers, Richard M. Terjemehan Yamin Magdalena (1997), Efektifitas Organisasi, Jakarta, Erlangga

Undang-Undang RI Nomor 32 Tahun 2004 tentang Pemerintahan Daerah. Penerbit Cemerlang Jakarta.

Wexley, Kenneth N, and Gary A. Yukl, 1992. Organizational Behavior and Personal Psychology, penerjemah : Moh. Shobaruddin, Jakarta : PT. Rineka Cipta.

Tesis/ Journal :

Warisno, 2008. Faktor-Faktor Yang Mempengaruhi Kinerja SKPD di Lingkungan Pemerintah Provinsi Jambi, Tesis, tidak dipublikasikan.

Eddy, 2003. Hubungan Gaya Kepemimpinan dengan Iklim Organisasi di lingkungan Sekretariat Daerah Kabupaten Muna," Tesis Magister, Makassar : Program Pascasarjana Universitas Hasanuddin.

Gunawan, 2004 "Pengaruh Pengawasan Melekat terhadap efektifitas Kerja Pegawai di Sekretariat Wilayah Daerah Tingkat I Sulawesi Tenggara Tesis Magister. Bandung : PPS UNPAD 